\title{
Civil society organizations and social innovation. How and to what extent are they influencing social and political change?
}

\author{
Carolina Andion \\ Rubens Lima Moraes \\ Aghata Gonsalves
}

ABSTRACT: This study aims to understand how civil society organizations (CSOs) perform and influence public arenas. The focus of this paper is the transformative scope of social innovation initiatives promoted by CSOs in two public arenas in Brazil: the fight against electoral corruption and the protection of children and adolescents' rights. The research consisted of three stages: 1) controversy mapping to understand the configuration of these public arenas and compare the trajectories of the public problems studied; 2) observation of the "field of experience" of some CSOs that perform in these arenas; and 3) analysis of "political grammars" produced in public arenas, connecting them to the performance of the CSOs analysed. The results reveal how social innovation emerges, develops and is disseminated in the public arenas studied and highlights the similarities and differences between the two cases, discussing the practices and role of CSOs in these processes. As conclusions, the study indicates that social innovation initiatives promoted by CSOs are influenced by and have an effect on the "political culture" in the public arenas. Additionally, this work states that the regime of CSOs' engagement in the public sphere and their performance have consequences in terms of influence on social and political changes. In the cases studied, when CSOs go beyond the logic of coproduction of public services and engage in "public inquiry" processes, their capacity to inspire social transformation seems to be enhanced.

KEYWORDS: Civil Society Organizations, Social Innovation, Social and Political Change, Public Arenas, Brazil. ECONLIT CODES: B5, H4, O3, R5.

How to cite this article: ANDION, C., MORAES, R.L. \& GONSALVES, A. (2017): "Civil society organizations and social innovation. How and to what extent are they influencing social and political change?", CIRIEC-España, Revista de Economía Pública, Social y Cooperativa, 90, 5-34.

Correspondence: Carolina Andion, Professor of the Center on Administration and Socioeconomic Sciences (ESAG) at the Santa Catarina State University (UDESC), Florianópolis, Brazil, where she leads the Research Group on Social Innovation in the Public Sphere (NISP), e-mail: andion.esag@gmail.com; Rubens Lima Moraes, Ph.D. Student in Political Science at Concordia University (Montréal, Canada), member of NISP, email: rubenslimamoraes@gmail.com; Aghata Gonsalves, Consultant for nonprofit institutional development at the Community Foundation for Greater Florianópolis (ICOM), member of NISP, e-mail: aghata.gonsalves@gmail.com. 


\section{RESUMEN}

\section{Organizaciones de la sociedad civil e innovación social ¿Cómo y en qué medida influyen en el cambio social y político?}

Objetivos: Este artículo tiene como objetivo comprender cómo actúan las organizaciones de la sociedad civil (OSC) y cual su influencia en las arenas públicas en Brasil. El estudio se centra en la dimensión política de la innovación social impulsada por las OSC y no sólo en sus dimensiones funcionales, económicas y / o técnicas, que tienen sido más consideradas en el debate académico reciente. La pregunta de investigación es la siguiente: ¿Hasta qué punto las iniciativas de innovación social promovidas por los actores de la sociedad civil en Brasil responden a los problemas públicos e influyen en las arenas públicas en que intervienen?

Diseño: Para responder a esta pregunta, este estudio abre un diálogo con las disciplinas de Sociología y Ciencia Política, que tienen una larga tradición de teorización sobre este tema y un contacto aún incipiente con el debate sobre la innovación social. El estudio adopta el enfoque de la Sociología Pragmática Francesa (Barthé et al, 2013, Frega, 2016), conectando los estudios de la Teoría Actor-Red (ANT) (Callon y Latour, 1981, Law, 1999, Latour, 1994, 2014) con el programa de investigación de la Sociología de los Problemas Públicos (Cefaï 2002, 2009, 2012, 2014, 2017, Chateauraynaud, 2011, 2016, Cefaï y Terzi, 2012, Quéré y Terzi, 2015). Estos enfoques teóricos ayudan a comprender las innovaciones sociales en cuanto prácticas, es decir, como procesos de cambio promovidos por la movilización y la participación de diferentes colectivos en la resolución de situaciones problemáticas en arenas públicas (Dewey, 1927). Por lo tanto, la innovación social no es vista como resultado de un ciclo evolutivo, pero como una colección de ajustes, atajos y desvíos que movilizan a una pluralidad de actores $y$, por lo tanto, implican altos niveles de incertidumbre. Tal como lo define Andion et al (2017: 50), la innovación social se relaciona con el proceso de "co-definición y co-dominio de situaciones problemáticas" y su estudio requiere observar la "política cotidiana" de los diferentes colectivos movilizados y engajados en torno a problemas públicos.

Metodología / aproximación: En términos de trabajo empírico, fueran investigados dos estudios de casos (longitudinales) en dos arenas públicas con fuerte participación de las organizaciones de la sociedad civil en el país: la lucha contra la corrupción electoral y la protección de los derechos de los niños y adolescentes. En el primero, el Movimiento Contra la Corrupción Electoral (MCCE) fue estudiado durante dos años, a través de la participación en eventos y campañas, observaciones directas y entrevistas con los miembros entre 2013 y 2014. En el ámbito de la protección de los derechos de los niños y adolescentes, la investigación de campo duró dos años (2014 y 2015). Los investigadores 
han acompañado el trabajo de 15 organizaciones de la sociedad civil y sus actividades como miembros del Consejo Municipal de Derechos de los Niños y Adolescentes (CMDCA) en la ciudad de Florianópolis. La investigación se llevó a cabo mientras estas OSC pasaban por un programa de capacitación promovido por la Universidad Estatal de Santa Catarina (coordinado por los investigadores en colaboración con una fundación comunitaria), que incluía seminarios y talleres en los que participaron otros 50 actores involucrados en la política pública, así como aproximadamente 130 niños y adolescentes de escuelas públicas y privadas de la ciudad.

Resultados: Los resultados se presentan en tres etapas: 1) cartografía de las controversias para entender la configuración de estas arenas públicas y comparar las trayectorias de los problemas públicos estudiados; 2) la observación de los "campos de experiencia" de OSCs que promueven innovaciones sociales en estas arenas; 3) el análisis de las "gramáticas políticas" producidas en estas arenas públicas y su relación con la actuación de las OSCs investigadas. Mediante la combinación de estas escalas de análisis fue posible observar cómo las innovaciones sociales emergen, se desarrollan y se difunden en los campos de causa analizados. También fueran tratadas las similitudes y diferencias en ambos casos, discutiendo de las prácticas y del papel de las OSCs en estos procesos. La comparación de los dos casos demuestra que la capacidad para producir procesos de innovación social no es la misma en los dos campos públicos analizados. Esta diferencia se relaciona con la "performance" de las OSCs (su práctica) o la forma como actúan en estos campos.

Limitaciones a la investigación / implicaciones: Una de las principales limitaciones de la investigación se refiere al hecho de ser un estudio sobre dos casos cualitativos que no puede ser generalizado. Sin embargo, este estudio se justifica por la representatividad de los casos estudiados y por la importancia de investigar más a fondo fenómenos de innovación social en arenas públicas y en países en desarrollo, con una cultura democrática aún no consolidada.

Conclusiones prácticas y valor original. Como conclusiones, el estudio indica que las iniciativas de innovación social promovidas por las OSCs sufren la influencia y tienen un efecto en la "cultura política" de las arenas públicas analizadas. Además, la forma de actuación de las OSCs en la esfera pública tiene consecuencias en términos de su impacto en los cambios sociales y políticos. En los casos estudiados, cuando las OSCs van más allá de la lógica de coproducción de los servicios públicos y promueven procesos de "investigación pública", su capacidad para inspirar transformación social parece ser ampliada. En la literatura reciente sobre innovación social, muchos autores reportan una cierta polarización en la discusión (Pol y Ville, 2009, Cajaibe-Santana, 2014, Lévesque, 2014, Montgomery, 2016, Andion et al, 2017). Esta polarización produce una oposición entre, por un lado, la escuela "Neo-Shumpeteriana" basada en el individualismo metodológico (Mumford, 2002; Murray, Caulier-Grice y Mulgan, 2010; Nicholls, 2010) y, por otra parte, el enfoque "Institucional" que se centra en procesos más amplios y a largo plazo de cambio en los valores, normas y esquemas cognitivos de la sociedad (Heiscala, 2007; Lévesque, 2014). Este estudio buscó superar esta polarización cen- 
trándose en las prácticas y demostrando que la capacidad creativa de los individuos, la acción colectiva y las dinámicas macroestructurales se influyen mutuamente en las experiencias de innovación social en arenas públicas (Cajaibe-Santana, 2014, Lehtola y Stahle, 2014, Frega, 2016). Así, el enfoque analítico-metodológico, los resultados y las conclusiones del estudio producen importantes aportaciones a la literatura sobre OSCs y innovación social, permitiendo comprender mejor la "política cotidiana" de estos grupos y su influencia en diferentes campos de causa, particularmente en países en desarrollo.

PALABRAS CLAVE: Organizaciones de la Sociedad Civil, Innovación social, Cambios Sociales y Políticos, Arenas Públicas, Brasil. 


\section{1.- Introduction}

The purpose of this study is to understand the social innovation processes promoted by civil society organizations (CSOs) in public arenas, a theme that is not widely explored in the literature as discussed by Rana et al (2014). This paper concentrates on the political dimension of social innovation driven by CSOs and not just on their functional, economic and/or technical dimensions, which have been increasingly considered in recent scholarly works (Galli et al, 2014; Gonzales et al, 2014; Franz, Tausz and Thiel, 2015; Seyfang and Longhurst, 2016). The research question is as follows: To what extent do social innovation initiatives promoted by actors of civil society in Brazil respond to public problems and influence the public arenas in which they operate?

To answer this question, this study opens a dialogue with the disciplines of Sociology and Political Science, which have a long tradition of theorizing about this subject (Cohen and Arato, 1994; Snow, Soule and Kriesi, 2004; Cefaï, 2007) but still-incipient contact with the social innovation field. The study adopts the focus of French Pragmatic Sociology (Barthé et al, 2013; Frega, 2016), connecting to the actor-network theory (ANT) (Callon and Latour, 1981; Law, 1999; Latour, 1994, 1999, 2012, 2014) and the research programme of the sociology of public problems (Cefaï 2002, 2009, 2012, 2014, 2017; Chateauraynaud, 2011, 2016; Cefaï andTerzi, 2012; Quéré and Terzi, 2015). These theoretical approaches invite us to describe social innovations through another lens (Andion et al, 2017; Moraes and Andion, 2017), understood as a practice, i.e., as a process of change promoted by mobilization and participation of different publics in resolving problematic situations (Dewey, 1927).

In terms of empirical research, two longitudinal case studies were investigated in two public arenas with strong involvement of CSOs in the country: the fight against electoral corruption and the protection of children and adolescents' rights. On the former, the performance of the Movement Against Electoral Corruption (MCCE) and its achievements were followed for two years, through participation in events and campaigns, direct observations and interviews with members between 2013 and 2014 (Moraes, 2014; Moraes and Andion, 2017). In the arena of protection of children and adolescents' rights, the field research lasted two years (2014 and 2015). The researchers traced the work of 15 CSOs and their activities as members of the Municipal Council of Children and Adolescents' Rights (CMDCA) in the city of Florianópolis. These CSOs operate as agents of the policy to guarantee the rights of children and adolescents in the city (Gonsalves, 2015; Gonsalves and Andion, 2017). The research was carried out whilst these CSOs went through a training programme promoted by the Santa Catarina State University (coordinated by the researchers in partnership with a community foundation), including seminars and workshops, in which 50 other actors involved with the public policy were engaged, as well as approximately 130 children and adolescents from public and private schools in the city. 
The methodological framework consisted of three distinct and complementary moments that did not occur in a linear way: 1) controversy mapping (Venturini, 2010a and 2010b) in macro public arenas to analyse the public debate and to represent the trajectory of public issues in which the initiatives were engaged; 2) monitoring of the "fields of experiences" (Cefai, 2014) of CSOs, seeking to follow the actor-network and their assemblages to retrace associations and understand the processes of engagement and mobilization around problematic situations (Latour, 2012); and 3) analysis of macro and micro scales in connection with seeking to understand the initiatives' incidence in public arenas in which they operate and discussion of social innovation processes promoted (or not) by these initiatives. The analysis highlights the relationship of "political grammars" (Boltanski and Thévenot, 2006) produced in public arenas with the experiences studied, seeking to draw more general conclusions about each of the cases studied and examine them together.

In the recent literature about social innovation, many authors report a certain polarization in the discussion (Pol and Ville, 2009, Cajaibe-Santana, 2014; Lévesque, 2014; Montgomery, 2016; Andion et al, 2017). This polarization produces an opposition between, on the one hand, a "Neo-Shumpeterian" strand based on methodological individualism (Mumford, 2002; Murray, Caulier-Grice and Mulgan, 2010; Nicholls, 2010) and on the other hand an "institutionalist approach" that focuses on broader and longer-term processes of change in the values, norms, and cognitive patterns of society (Heiscala, 2007; Lévesque, 2014).

This study sought to overcome this polarization by focusing on practices and showing that the creative capacity of individuals, collective action and macro-structural dynamics influence each other in social innovation practices (Cajaibe-Santana, 2014; Lehtola and Stahle, 2014; Frega, 2016). Thus, the analytical-methodological approach, results and conclusions of the study bring important contributions to the literature on CSOs and social innovation, enabling a better understanding of the "everyday politics" of these groups and their influence on different public arenas, particularly in developing countries.

The next sections present the results of the study and are structured in three parts. The first section explores the debate on civil society's influence over the public sphere, offering a particular understanding of civil society's action in the public arenas that gives a fundamental place for these actors in the public action. The second section debates the configurations and trajectories of the two public arenas analysed, highlighting their similarities and differences, showing the "political culture" (Cefaï, 2009) in which practices of the CSOs are inscribed. The third section investigates the experiences of the national network of the MCCE and a network of CSOs that work together on the public policy to guarantee the rights of children and adolescents in the city of Florianópolis. The comparison of the two cases enabled drawing some conclusions on how social innovations emerge, develop and are disseminated in public arenas analysed, and highlights the similarities and differences between the two cases, discussing the practices and role of CSOs in these processes. 


\section{2.- Public action, civil society organizations and social innovation}

Many of the recent studies about civil society and social innovation place an emphasis on the functional and economic perspectives of the phenomenon. As discussed by Meyer, Buber and Aghamanoukjan (2013: 191), "innovation has evolved into the key account for legitimation in a new stage of managerialism" in CSOs. Social innovation is generally described as a way for civil society to contribute to government and coproduce or co-create public policies, making improvements and reducing costs in public services (Galli et al., 2014; Gonzales et al., 2014; Merickova, Nemec and Svidronova, 2015; Seyfang and Longhurst, 2016). In this sense, this literature underestimates the political aspect of social innovation and the weight of civil society actors in social change, aspects that this study seeks to emphasize.

To shed light on this connection between social innovation and social and political change, this paper proposes a dialogue with French Pragmatic Sociology (Barthé et al, 2013; Frega, 2016). Specifically, two main approaches are related in this study: the actor-network theory (ANT) (Latour, 1994, 1999, 2012, 2014) and the sociology of public problems (Cefail 2002, 2009, 2012, 2014; Chateauraynaud, 2011, 2016; Cefaï and Terzi, 2012). This dialogue allows us to conceive another interpretation of the role of CSOs in the public action (Andion et al, 2017), which highlights the political dimension of social innovation dynamics and their incidence in social change.

The pragmatist authors are inspired by Dewey (1927) and his discussion of the relation between civil society and the State. In his seminal work The Public and Its Problem, Dewey affirms that the State does not exist without the configuration of "publics" that emerge from the apprehension of the consequences of the associative life. He argues that State formation is an experimental process that implies the organization of "publics" and the construction of a civic culture, related to the ability to find solutions to problematic situations (Cefaï, 2012).

This process is linked with the possibility to develop free "social inquiry" (Dewey, 1927: 218) and its diffusion. This refers to the ability of "the publics" to develop a "social intelligence" or to collaboratively and systematically develop knowledge to understand the consequences that affect the associative life. For him, this process gives reality to public opinion.

Thus, Dewey (1927) anticipated a discussion that is very alive in the field of public administration, which is related to the reconfiguration of the contemporary State, a process reinforced after the Welfare State crisis (Thoenig and Duran 1996; Bernier, Levesque and Bouchard, 2003; Denhardt and Denhardt, 2003). As stated by these authors, the term "public policy" loses ground to the notion of "public action" (Lascoumes and Le Galès, 2007). Public action is about a transition from a model where the State uni- 
laterally controlled the policies' design and implementation to an idea of collective action and intelligence, involving a plurality of actors to respond to public problems. This implies greater fluidity, heterogeneity and fragmentation of political power and major changes in public policymaking processes, as summarized in Table I.

\section{Table 1. Changes in the public policymaking processes}

\begin{tabular}{|l|l|l|}
\hline Dimension & Centrality of the State & Multicentric Collective Action \\
\hline $\begin{array}{l}\text { Lanagement } \\
\text { Locus }\end{array}$ & $\begin{array}{l}\text { The State's management follows } \\
\text { principles of verticality and } \\
\text { compartmentalization } \\
\text { (Top-Down Model) }\end{array}$ & $\begin{array}{l}\text { The management is territorialized and transversal, } \\
\text { targeting problems that are common to the local } \\
\text { collectives }\end{array}$ \\
\hline State's action & $\begin{array}{l}\text { Theory of the unitary State (regulation } \\
\text { towards stability, centralized) }\end{array}$ & $\begin{array}{l}\text { Processual public action (flow of challenges, } \\
\text { heterogeneity of territories and political power) }\end{array}$ \\
\hline $\begin{array}{l}\text { Logic of the provision } \\
\text { of public services }\end{array}$ & $\begin{array}{l}\text { Service provision through service } \\
\text { centres, technocratic and distributed } \\
\text { in sectors }\end{array}$ & $\begin{array}{l}\text { Co-creation of public action: collective identification } \\
\text { and delimitation of public problems. Collective creation } \\
\text { of solutions and participation }\end{array}$ \\
\hline Criteria for legitimacy & $\begin{array}{l}\text { Technical, juridical and economical } \\
\text { legitimacy }\end{array}$ & $\begin{array}{l}\text { Political legitimacy. Capacity of coordinating, } \\
\text { connecting and networking }\end{array}$ \\
\hline Central actors & Elected politicians and public servants & Multiple actors and interests (institutional polyarchy) \\
\hline Relationship among \\
actors & $\begin{array}{l}\text { Logic of competition, political bargaining, } \\
\text { compensation (secrecy and divergence } \\
\text { between formal and informal, laws and } \\
\text { facts) }\end{array}$ & $\begin{array}{l}\text { Logic of negotiation and communication: public } \\
\text { problems demand multiple expertises and shared risks }\end{array}$ \\
\hline $\begin{array}{l}\text { Role of collective } \\
\text { action }\end{array}$ & $\begin{array}{l}\text { Local collectivity submitted to central State, } \\
\text { as beneficiaries or clients }\end{array}$ & $\begin{array}{l}\text { Local collectivity as subjects, actors and protagonists } \\
\text { of public action }\end{array}$ \\
\hline $\begin{array}{l}\text { What is valued } \\
\text { (evaluation) }\end{array}$ & $\begin{array}{l}\text { Logic of success of the result based on } \\
\text { efficiency and efficacy of the processes }\end{array}$ & $\begin{array}{l}\text { Logic of shared risks, action effectiveness, the results } \\
\text { and social impact generated }\end{array}$ \\
\hline
\end{tabular}

SOURCE: Adapted from Andion, Becker and Victor (2012).

In addition to bringing up the notion of "public action" and giving importance to the influence of civil society on this action, some pragmatist authors (re-)discuss the place in which this action occurs. For them, "public arenas" become central to politics when shared governance (Osborne, 2010) is in place. It is important to observe that the public sphere is redefined in comparison with the classical conceptualization (Habermas, 1984; Arendt, 1991). This is because currently public spaces are more hybrid, dynamic and virtual, characterized by multiple actors interacting. According to Cefaï (2012), "public arenas" are spaces of confrontation and cooperation in which public problems are (re-)signified and shared. It is a space where actors, at different levels and in addition to the State agencies and structure, connect and mobilize. 
Considering the discussion above, this paper proposes an understanding of multi-centric public policy (which considers various actors as protagonists), resulting from a "public action", performed in public arenas. This notion seeks to connect practices, subjects, institutions and technical and legal mechanisms in a process of constant interaction. Therefore, this study is aligned with Lascoumes and Le Galès (2007: 32), who argue that public policies are "collective actions participating in the creation of a specific social and political order, of the direction of society, regulating its tensions, integration of groups and conflict resolution". However, how can we analyse and observe this public action? More than a "new concept", it is necessary to come up with "another way to look at" this action.

According to pragmatist authors (Chateauraynaud, 2011; Cefaï and Terzi, 2012; Cefaï, 2014), analysing public policies as "public actions" means observing them while they are being produced. In other words, it implies observing how the processes of experimentation and policy implementation flow. This is a pragmatic analysis of public actions, which allows focusing on the experience of multiple actors at different levels and situations in public arenas, as well as taking into consideration the consequences of these experiences on public problems.

More than explaining what is already in place, the task is thus to understand the dynamics of the process of change (Latour, 2012), the process of "social innovation" that occurs at the intersection of the macro and micro social scales. In accordance with Cajaibe-Santana (2014) and Lehtola and Stahle (2014), this study considers that collective (and not just individual) action and macro-structural dynamics mutually influence social innovation processes. In this sense, it is possible to overcome the opposition noted above between the "Neo-Shumpeterian" and the "Institutionalist" approaches (Pol and Ville, 2009, Cajaibe-Santana, 2014; Lévesque, 2014; Montgomery, 2016; Andion et al, 2017).

In this sense, social innovation is understood here as a practice, i.e., an engine of "social being built" (Latour, 2012). Thus, social innovation is not a result of an evolutionary cycle but rather a collection of adjustments, shortcuts and detours that mobilize a plurality of actors and, therefore, involve high levels of uncertainty. As defined by Andion et al (2017: 50), social innovation is related to the "process of co-definition and co-dominium of problematic situations", and studying it requires one "to observe day-to-day politics of the different collectives mobilized around public problems".

Understanding this dynamic requires connecting levels of analysis and dimensions often considered mutually antagonistic in classical sociology. First, it is important to understand the macro-structures of public action. To put the focus on the macro-structure level - seeking to understand the process of configuration of public problems over time - the theoretical foundations of the actor-network theory (Latour, 2012), and specially the cartography of controversies (Venturini, 2010a; 2010b; Venturini et al. 2015), are employed.

According to the authors, this macro-structural perspective must, however, be related to the description of the "field of experience" (Cefai, 2014) of the public, seeking to respond to problematic situations, recognizing that common practices and individual and collective experiences (re)interpret and (re)con- 
figure what was in place. To make this possible, the theoretical perspective of the Sociology of the Public Problems (Cefaï, 2002, 2007, 2009, 2012, 2014; Cefaï and Terzi, 2012; Quéré and Terzi, 2015) is also taken into consideration.

As indicated by Cefaï (2012), the experience of public problems involves disputes, conflicts and controversies, thereby experiencing the problem based on reality. As a result of these processes, different audiences may or may not reconcile their world views to connect effective responses to the same problem. This process of interaction (between humans and non-humans) can be organized in flexible and mobile networks of individual and collective actors, connected by common concerns and joint activities. A pragmatic analysis understands public action in this "intercommunication web", which is built by coordinating experiences and social activities (Cefaï, 2012). As stated by Duran and Thoenig (1996), today's public problems require multiple expertises and risk sharing. This requires communication, coordination and networking to face such problems by different actors involved in public arenas.

In the next sections, the analysis of two network experiences of CSOs are presented, based on these theoretical assumptions. First, the configurations and trajectories of the public arenas are portrayed. Second, the characteristics of CSOs' performance in the two arenas are analysed, underlining their similarities and differences and intending to demonstrate the different practices, visions and forms of promoting social innovation in the two political fields studied.

\section{3.- Cartography of controversies in the public arenas}

To understand the public arena configurations and trajectories, an exploratory mapping in three fields - political, scientific and legal — was carried out (Latour, 2014). The interrelation of the debates in these fields produced a narrative about the two public arenas, in four decades, from the 1980s to the 2010s (Moraes, 2014, Gonsalves, 2015, Moraes and Andion, 2017). In this section, we will synthetize and compare two decades, the 1980s and the 2010s, aiming to underline the transformations in that period.

In the political field, we examined articles from free newspapers with large circulations in Brazil1. In the scientific field, the mapping was done through surveying articles published in scientific data-

1.- The newspapers chosen were "O Globo" and "Folha de São Paulo", two of the largest and most influential newspapers in the country (ANJ, 2014). They provide an online platform that allows access to the digital version of all the pages and articles in the newspapers published since their first editions. In the arena of guaranteeing children and adolescents' rights, the research on news was performed twice using the exact term in Portuguese "direitos da criança" (children's rights) and "direitos da criança e do adolescente" (children and adolescents' rights). The criterion to filter the results was news published in the newspaper section "O pais" (The country) in the period from 1985 to July 2015. Excluding the repeated results, the search generated a total of 283 news items. In the fight against electoral corruption arena, the timeframe of the newspaper mapping began in 1988, which marks the moment of the democratic opening in Brazil. The method employed to search the news was entering the keyword "electoral corruption" from 01/01/1988 to 09/11/2014. In total, 80 articles were found in the chosen news outlet. 
bases $^{2}$. In the legal field, the main laws governing the subject matter ${ }^{3}$ in the country were considered.

This resulted in an inventory of the public (individuals, organizations and institutions) that mobilized around the problem in the political, scientific and legal fields in each decade. In addition to mapping the network actors, their statements were analysed to identify themes of controversies and world views (cosmoses), i.e., the meanings they attach to the public problem (Venturini, 2010a, Latour, 2012). This allowed reconstituting a narrative that highlights the course and form of "expression of criticism" (Chateauraynaud, 2011), essential for the production of social innovations in each of the fields of cause studied.

\subsection{Arena of Electoral corruption}

As demonstrated by Moraes and Andion (2017), the configuration of the problem of electoral corruption in Brazil occurs mainly from the mid-1990s, when the process of the development of a plural "public arena" begins to occur. In this moment and after, we observe a diversification of collectives that mobilize around the public problem, especially linked to public control (public officers) and social control (civil society organizations) (figure 1).

The analysis shows that the debate shifts from the private domain - mainly linked to accusations and scandals - to the public domain. In the 2010s, spokespersons of the problem are no longer politicians, as in the 1980s, but rather include public officers (from the executive, judiciary, public attorney's office and legislature) and a diversity of civil society actors. The formation of these new publics gives rise to other "cosmovisions" (Latour, 2012) about the problem of electoral corruption and its causes, consequences and solutions to combat it.

In addition to a "palliative vision", which links electoral corruption with "bad and deviant behaviours" in a moral perspective - argumentation prevalent in the debate in the 1980s - new interpretations of the problem emerge in the 1990s and 2000s. This includes the debate about punishing electoral cor-

2.- In the arena of guaranteeing children and adolescents' rights, data collection was carried out through a systematic search in the Ebscoß, Scielo ${ }^{2}$ and Web of Science $®$ databases with the terms in Portuguese "direitos" (rights) and "crianças e adolescentes" (children and adolescents) to understand the scientific discourse on the subject, generating a total of 379 articles from 1985-2015. The analysis of the articles was made using the software EndNote@, refining the references found, excluding repeated articles and keeping only articles on Social Sciences, Health Social Sciences and Education about the reality of Brazil. Thus, 123 articles formed the sample and were analysed. In the fight against electoral corruption arena, articles published on the subject in social sciences were searched in SciELO®, EBSCO® and Annals of the National Association of Graduate Studies and Research in Administration (AnpadQ). The researched period was also from 1988 to 2014 and considered only articles published in Brazil, utilizing the keyword "electoral corruption". Only 12 scientific papers were identified.

3.- In the electoral corruption arena, the previous regulation of the Constitution of 1988 was also analysed in an attempt to understand the different amendments enacted over time. Legal references from the 1990s were considered, such as the Law of Ineligibility, Complementary Law 64/1990, Elections Act (Law 9504/1997) and Law on Political Parties (Law 9096/1995). Laws created by popular initiative in the 2000s were examined. The recent proposals for political reform were also reviewed, particularly the People's Initiative Bill 6316/2013. In the legal field of children and adolescents' rights, the search was carried out in the Federal Government Portal of Legislation, from 1985 to 2015. The search yielded 262 results, including 01 Federal Constitution, 01 Brazilian Child and Adolescent Rights Act (ECA), 184 decrees, 13 provisional measures, 02 constitutional amendments, and 61 ordinary laws. For the sample, the Federal Constitution, ECA, constitutional amendments and laws were prioritized, resulting in 65 legal documents. 
ruption ("punitive vision"), through investigation and condemnation of electoral corruptors. During this period, a discussion about the importance of institutional changes in the Brazilian electoral system to increase the effectiveness of the combatting of electoral corruption also begins. In this period, discussions about inefficiency of the legislation and electoral system and the importance of democratic controls dominate the public debate.

The trajectory of argumentation (Chateauraynaud, 2011), especially after the 2000s, shows a process of continuous intensifying of the debate about electoral corruption in Brazil and the production of agreements by the stabilizations or "black boxes" (Latour, 2012) that emerges. This is illustrated by the expansion of the legal framework on the subject, involving, for example, the implementation and social control of the Law Against Vote Buying (Law 9840/1999) and the approval of the Clean Record Law (Law 518/2009), both of which are laws based on popular initiative. All these changes will produce situations of criticism, amplifying the argumentative capacity of the actors.

In the 2010s, the "preventive" vision of combatting electoral corruption is strengthened. In addition to the causes already discussed in the public debate of the 2000s, such as the inefficiency of laws and the importance of the system of punishment, in 2010 new controversies emerge around the financing of electoral campaigns. Newspaper and other mass media discuss controversies linked to private donations to parties and campaigns, the use of slush funds by candidates and the lack of transparency in the accounting of electoral campaigns. These themes converted in hot topics in the public debate in the 2010s and became more popular after the "car wash" (Lava Jato) operation conducted by federal policy and public prosecution.

\section{Figure 1. Representation of the spokespersons in the debate in the field of electoral corruption in Brazil (1980s and 2010)}
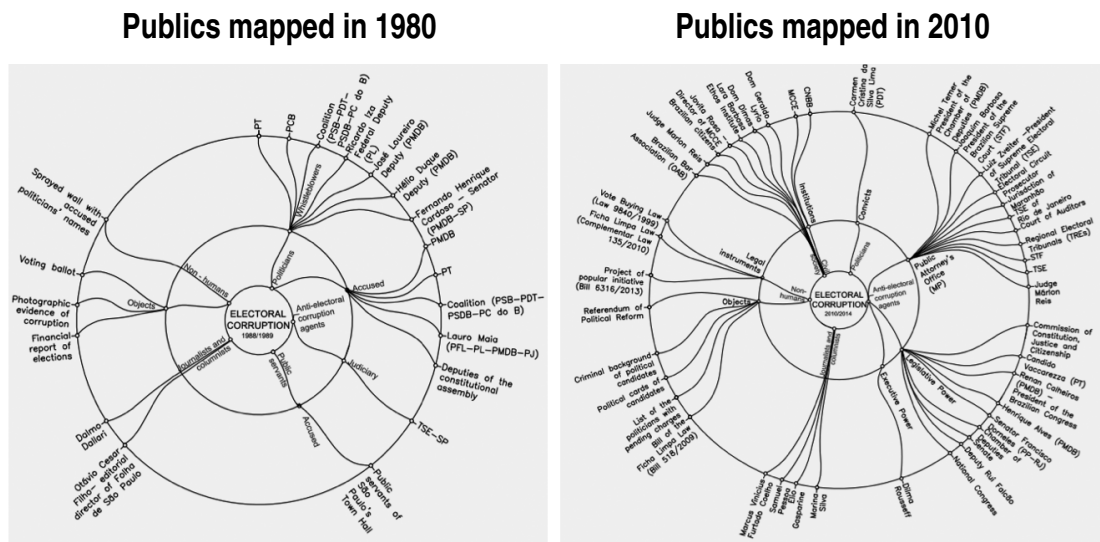

SOURCE: Moraes and Andion, 2017. 
Transparency and accountability are also themes of debate in both the academic and political fields in the 2010s. There is also an increase in the debate on social control practices related to citizen education and social accountability. Another important subject of controversy relates to the political reform proposed by Bill $6.313 / 2013^{4}$, of which some proposals, such as the end of campaign business financing, have already been implemented.

This trajectory brings into focus a clear (re) configuration in the landscape of the public arena of electoral corruption in Brazil. This transformation is closely associated with the mobilization of a collective of publics related to experts from the judiciary (working and retired), media and civil society actors that engage with the public problem and provide the material of enduring opinion (Dewey, 1927) about "electoral corruption". The influence of the network of CSOs in this process is crucial, as discussed in the next section.

\subsection{Arena of Protection of Children and Adolescents' Rights}

As discussed by Gonsalves and Andion (2017), the analysis of the public debate in this arena shows that three measures - institutionalization, regulation and judicialization - seem to be the main paths taken to address public problems and promote children and adolescents' rights in Brazil. The effects of this choice lead to numerous distortions that are now questioned, re-opening the "black boxes" and generating new controversies on issues that were thought to be resolved (Latour, 2012). Among these effects, we can highlight: (i) overestimation of the institutional-legal apparatus facing the public problem, especially those related to violation of rights; (ii) treatment of children and adolescents as "beneficiaries" of the policies, seen as either victims or perpetrators; (iii) a depreciation of the central role of families and communities in guaranteeing rights, as established by the Constitution; and (iv) a look at the guaranteeing of rights linked especially to combatting violations with a vision more punitive than based on prevention or promotion of rights.

These aspects are consequences of a growing process of demobilization and disengagement of the publics around the cause over time. However, a large expansion of the institutional apparatus and the adjudication of cases related to the violation of rights can be observed. This process is more visible historically.

In the 1980s, the prevailing view that fuels public debate is that of formally recognizing the rights of children and adolescents. There is an understanding during this period that the institutionalization of rights and the creation of devices for its implementation will be the way to ensure that Brazilian children

4.- The proposal is drafted by the Coalition for Democratic Political Reform and Clean Elections, formed by a network of 103 CSOs (including the MCCE). The Bill aimed to amend the Electoral Code (Law No. 4,737 / 1965), Election Law (Law 9505/1997) and Law on Political Parties (Law n. 9,096 / 1995). The central idea of the project is to propose political reform ending private corporate financing of electoral campaigns, creating a voting system in which, first, the citizen votes in a party and, after, he votes for the candidates of the party elected, chosen by the members of that party. Another proposal is to end the restrictions on freedom of expression on the internet before the election period, which is not permitted by the actual legislation. 
and adolescents have their rights guaranteed, from a republican (universalization) perspective. We have here an important period of denunciations and mobilizations within the public arena, which will be the engine of important institutional advances in the next decade. During this period, the role of the Catholic Church, the nascent social movements and UNICEF are crucial as they present themselves as spokespersons for guaranteeing the rights of children and adolescents (figure 2).

\section{Figure 2. Representation of the spokespersons in the debate in the field of Protection of Children and Adolescents' Rights (1980 and 2010)}

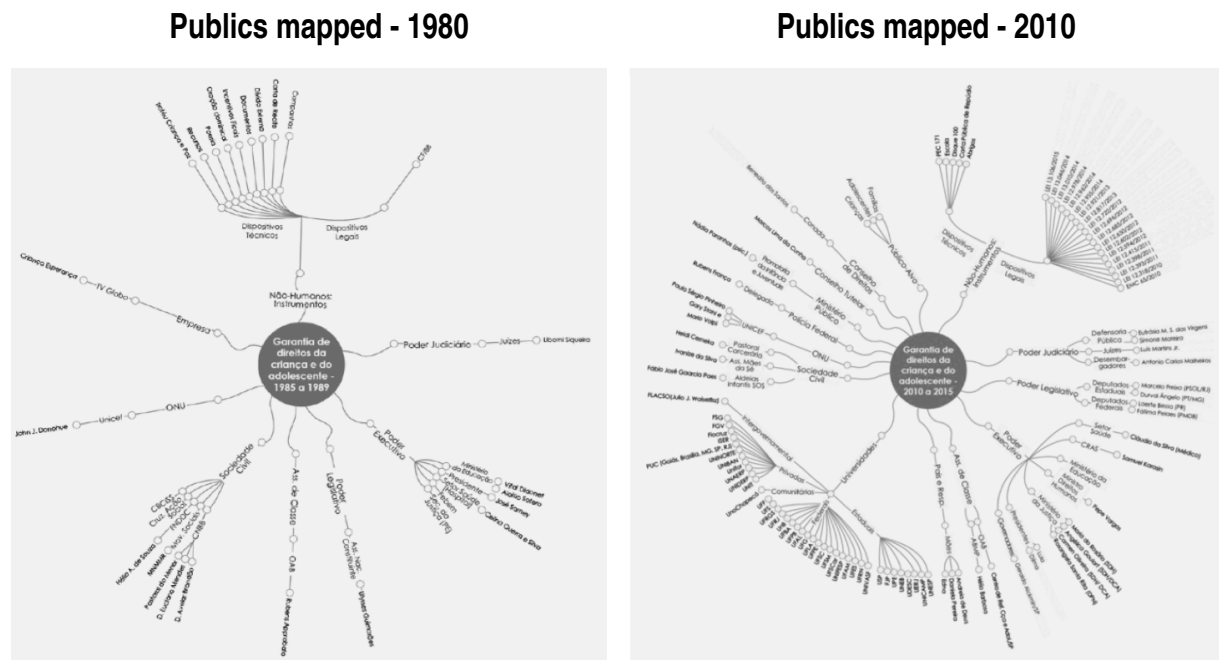

SOURCE: Gonsalves and Andion, 2017.

However, when we analyse the debate of the 1990s, we observe a change in the trajectory of the argumentation in the public arena. The focus of attention changes, and combatting the violation of rights becomes a central point in the public debate. Instead of worrying about the universalization of rights and integral protection (the driving force of mobilizations by constituents), we observe a concern with reporting and investigating cases of rights violations. This is evidenced by the larger number of reports and denunciations of child labour, children and adolescents out of school, victims of sexual abuse and exploitation, and other such issues. In these investigations, the actions of the security and control organs, such as public prosecution, the federal policy and national council of children and adolescents' rights (Conanda) stand out as a way of addressing such violations. In addition to governmental action, companies, institutions and business foundations operate through Private Social Investment (ISP), also directing resources to CSOs, through the fund for children instituted by the Children and Teenagers Act (ECA) of 1990. 
Later, in the 2000s, we observe greater specialization of the public action and the treatment of problems related to children and adolescents (still associated mainly with cases of violations). In all three fields (scientific, technical-legal and political), we observe efforts to identify, measure and understand the public problem more deeply through systematic investigations and research the causes and consequences of the violation of rights in the country. There is greater concern of the actors with the criminal responsibility of the aggressors and violators of rights. Several campaigns against violations are carried out, and pressure is put on the judiciary to expedite punishment processes.

Additionally, various laws are created, defining new crimes and intensifying sentences for various types of violence committed against children and adolescents. An important debate that emerges in the 2000s and intensifies in 2010 criticizes the gap between what is established in the legislation and the instruments for operationalization of the policy and its effects. More recently, we see a discussion of the inefficiency of the policy and its inability to respond to the numerous cases of violation, as well as the undesirable consequences of the option for institutionalization and judicialization to avoid violation of rights. Although the legislation has established new guiding principles, such as full protection, as well as political-administrative decentralization, with the municipalization of politics, the debate denounces the permanence of world views, practices and instruments, which seem only to "change their name" after the ECA promulgation.

This gap between legislation and practice is criticized, especially in the scientific field, which will also analyse initiatives that seek to reduce this gap between regulation and practice. This vision of "policy failure" intensified in 2010 with the effects of implementing the ECA, after 20 years of its existence, reopening several "black boxes" and reflecting on the efficiency and effectiveness of the policy, its strategies and its instruments.

In this sense, a debate emerges about other forms of guaranteeing rights, such as the strengthening of family ties and community coexistence of children and adolescents. This means the re-evaluation of a vision of integral protection, based on a preventive logic and a universalization of rights and not just a punitive view aiming to combat their violation. For these aspects, the recent academic debate seems to play an important role as an "alert launcher" (Chateauraynaud, 2011).

However, the return of the discussion of the criminal majority brings to the centre of the debate "old" visions or conceptions of the problem that already seemed to have been overcome or stabilized. The hegemony of a traditional "political culture" seems in this case to still influence the experience of public action (Cefaï, 2002). 
The reconstitution of the debate in each of the public arenas analysed shows that the emergence and projection of a cause in public space is not a random phenomenon but rather is the result of political mobilization. The reconstitution of the "narrative component" (Terzi, 2015) in these fields shows the forms of dispute and controversy or the "modes of expression of criticism" (Chateauraynaud, 2011) that collective mobilizations in these arenas assume over time.

Comparing the two narratives, we can see that the trajectories of the public debate in these two arenas are quite different. Whereas in the field of electoral corruption there is an increase in debate and problematization of the public problem, in the arena of protection of children and adolescents' rights, there is a decline in public debate and engagement around this cause. A recursion of certain controversies is also observed, showing that old issues, such as the interpretation of children and adolescents as "minors", have not yet been supplanted. However, the commitment to institutionalization, regulation and judicialization, while increasing the complexity of the system to tackle the public problem, diminishes the involvement of important actor-networks, such as families and children and adolescents.

This shows that the socio-historical backdrop of disputes in these fields and the argumentative capacity of the spokespersons of civil society in these two fields are distinct. This leads to the hypothesis that this "political culture" is influenced by (and affects) the performance of CSOs (Soule and Olzak, 2004). In other words, social innovation initiatives promoted by CSOs could act as catalytic vectors of this "public culture", and this "public culture" also has influence on social innovations (accelerating or limiting them) (Quére and Terzi, 2015). In this sense, social innovation does not occur in a vacuum. It emerges in a field of a cause and is supported by arguments, meanings and practices built on the public issue over time (Andion et al, 2017).

Empirically exploring this hypothesis, this research investigated whether the difference between the dynamics of social transformation in the two arenas analysed has a relation to the performance of the CSO network in these fields. Following the traces presented by Simsa (2003), it was observed that the influence on social and political change of the CSOs studied in these two fields is quite different. This influence not only varies but is essentially determined by the different CSOs' performance in these public arenas. In the next section, this relationship is discussed, specifying evidences found in the fieldwork on the two researched initiatives. 


\section{4.- Civil society organizations and social innovation in the public arenas: practices and performance}

\subsection{Trajectory and performance of the Movement Against Electoral Corruption}

The MCCE is responsible for mobilizing Brazilian society to approve the only two anti-corruption popular initiative laws in Brazil. The first, Law $9840 / 1999$ (Law Against Vote Buying), allows for the voiding of electoral records and diplomas by the practice of buying votes or of the electoral use of the administrative machine. The second, Supplementary Law 135/2010, popularly known as the Clean Record Law, forbids the election of politicians who have been sentenced for a crime in a collective decision, when politicians are deposed by the Brazilian Electoral Justice or for those who waived an elected position to avoid the impeachment process. Currently, the MCCE is mobilizing towards a project for broader political reform, as noted above. The movement is formalized in 2002, with the gathering of 30 committees that were already in place in defence of Law 9840 (MCCE, 2014); however, its network begins forming in the late 1980s, as shown in Table II.

The Executive Secretariat was founded in August 2006 and formalized in April 2007. The MCCE is described as a non-profit and economic, democratic and pluralistic association with unlimited duration, with headquarters in the Federal Council of the Brazilian Bar Association (OAB) in Brasilia (MCCE, 2014). The Secretariat's objective is to support and strengthen policies and actions of the National Committee. The movement is also organized locally, through local committees in all the regions of the country (Figure 3). Additionally, the National Committee has the support of many civil society organizations, among which stand out the National Conference of Brazilian Bishops (CNBB) and Brazilian Bar Association (OAB).

\section{Figure 3. MCCE Committees}

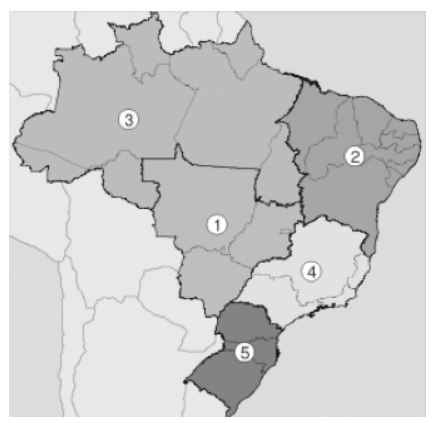

1. Midwest Region: 28 committees

2. Northeast region: 109 committees

3. North Region: 36 committees

4. Southeast Region: 113 committees

5. South Region: 43 committees

SOURCE: MCCE, 2014. 
To describe the "field of experience" of the MCCE, different research strategies were used (Moraes and Andion, 2017), including extensive fieldwork between August 2013 and October 2014. In this period, different research strategies were employed: 1) direct observation of MCCE scenes, events and activities (participation in campaigns, seminars and visits); 2) online monitoring of news about the MCCE and other topics published on their site and from other internet sources during the research period; 3 ) document-based analysis of references already published about the movement (Reis, Oliveira and Castro, 2010, Reis, 2013 and 2014) and news about the experience (from 1988 to 2014); and 4) six interviews with founders, directors, technicians and other members of the movement. The triangulation of these methods makes it possible to portray and analyse the MCCE case from a descriptive, interpretative and qualitative perspective (Godoy, 2006).

The case study showed that the movement has undergone a "broadening of its publics" (Cefai, 2009). First, the movement is mainly represented by organizations linked to the Catholic Church. After the approval of the Law Against Vote Buying, the various committees that give rise to the MCCE are created. The number of committees considerably expands through the creation of the Clean Record Law. Over time, the MCCE network changes with the adherence of other civil society entities that emerge in the public arena of electoral corruption. Currently, the MCCE network consists of 55 civil society organizations, as shown in Figure 4.

In fact, the network that makes up the MCCE is formed by the association of a "constellation" of collectives (Cefai, 2009) that mobilize around the movement, in addition to the members of the National Committee and Local Committees. It includes: (1) members of the Catholic Church and related institutions, such as bishops, priests, parish members, the Justice and Peace Commission and the CNBB, which has played an important role in the stabilization of the network, from its origin until today; (2) specialists, OAB lawyers, electoral judges, ex-promoters, and university researchers; (3) the different legal and institutional instruments and mechanisms existing and created in this experience, which are "mediators" in the actions; (4) online activists and related objects, such as Avaaz members, the internet, social networks and digital devices responsible for the way the movement mobilizes; (5) the mass media and journalists who played a decisive role in this trajectory in the 1990s during the campaign to collect signatures for the Law Against Vote Buying; and (6) other social movements and civil society organizations working with similar guidelines in the fight against corruption, together with the MCCE. 
Figure 4. Civil society organizations supporting the MCCE

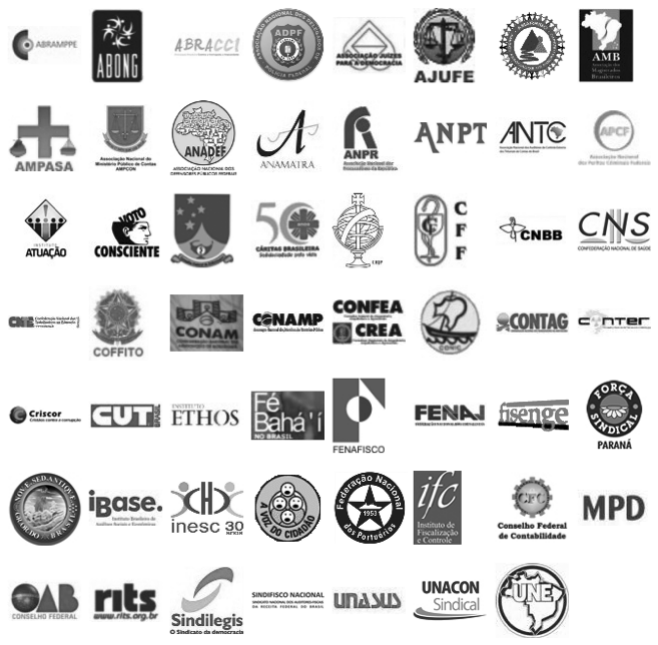

SOURCE: MCCE, 2014.

As discussed by Moraes and Andion, 2017, a myriad of collectives combine their expertise and skills and thus produce a collective intelligence (Lévesque, 2014) about the public problem of electoral corruption over time. Social innovation here is not the work of a "single inventor" but rather is configured as a "collective and procedural co-construction" (Latour, 2012).

The MCCE network changes at the same time that it promotes social change (Mische, 1994). Their forms of organization and mobilization change over time from face-to-face mobilization through church work to a more networked and organized mobilization, with the expansion of organizations linked to the movement until it reaches net-activism more recently. These changes seem to reflect the transformation in the setting of the "public problem" as shown in table 2, which summarizes the trajectory of the MCCE and the important moments of inflexion (trial situations) where social innovations were observed. 


\section{Table 2. Trajectory of MCCE: a synthesis}

\begin{tabular}{|c|c|c|}
\hline Trials/Moments of Proof & Marks & Outcomes / Social Innovation \\
\hline $\begin{array}{l}1985-1988 \\
\text { The roots of the } \\
\text { movement }\end{array}$ & $\begin{array}{l}\text { - Publicizing of electoral corruption } \\
\text { - Participation in the Constituent Assembly } \\
\text { - Proposal of specific institutional framework devices } \\
\text { in the Federal Constitution that ensure civil society } \\
\text { involvement in the public sphere }\end{array}$ & $\begin{array}{l}\text { Addition of Article } 14 \text { of } \\
\text { the Federal Constitution } \\
\text { (1988) }\end{array}$ \\
\hline $\begin{array}{l}1989-1999 \\
\text { Mobilization to pass } \\
\text { a Law Against } \\
\text { Vote-Buying }\end{array}$ & $\begin{array}{l}\text { - Fraternity Campaign in } 1996 \\
\text { - Research in the parishes of Brazil about major electoral problems } \\
\text { - Drafting of Bill 1517/1999 (Vote-Buying Law Project) } \\
\text { - Mobilization to approve a Popular Initiative Law } \\
\text { - By the end of 1998, the mobilization by signatures } \\
\text { stagnates (500,000 subscribers), and the organizers } \\
\text { consider quitting } \\
\text { - The Mafia of Inspectors scandal gives the new campaign } \\
\text { a 2nd wind, and the campaign reaches } 1 \text { million signatures } \\
\text { in } 1999\end{array}$ & $\begin{array}{l}\text { Law no. } 9840 \text { - } \\
\text { 'Law Against Vote Buying' } \\
\text { (September 1999) }\end{array}$ \\
\hline $\begin{array}{l}2000-2009 \\
\text { Institutionalization } \\
\text { and network } \\
\text { formation }\end{array}$ & $\begin{array}{l}\text { - Accusations and scandals in cases of elected politicians involved } \\
\text { in crimes } \\
\text { - Clean Record Bill 518/2009 Project written by members of CNBB } \\
\text { with support of judges and prosecutors } \\
\text { - Signatures are collected for approval of a new popular initiative law } \\
\text { - Media and community mobilization } \\
\text { - Utilization of social networks and Avaaz platform on the internet } \\
\text { - In September 2009, } 1.3 \text { million signatures are filed in Congress } \\
\text { - Resistance in the Chamber of Deputies and Senate to approving } \\
\text { the law. Politician mobilization (calls) and presence in the sessions } \\
\text { is undertaken to approve the law }\end{array}$ & $\begin{array}{l}\text { Clean Record Law } \\
\text { (Complementary Law } \\
135 / 2010 \text { ) enacted by } \\
\text { President Lula in } 2010 \\
\text { and ruled constitutional } \\
\text { by the Supreme Federal } \\
\text { Court (2012) }\end{array}$ \\
\hline $\begin{array}{l}2010-2015 \\
\text { Spread of the network } \\
\text { and the agenda of } \\
\text { the movement }\end{array}$ & $\begin{array}{l}\text { - In the 2010s, political reform becomes a hotspot in the public arena } \\
\text { of electoral corruption } \\
\text { - Direct Action of Unconstitutionality (ADI) is filed by the OAB in } \\
\text { Supreme Federal Court in } 2014 \\
\text { - The Clean Election Campaign does not continue } \\
\text { - A new popular law project is created and registered as } \\
\text { PL } 6.316 / 2013, \text { known as Political Reform } \\
\text { - A minor Political Reform is approved by the Chamber of Deputies } \\
\text { in } 2014 \text { without taking into account the agenda of civil society }\end{array}$ & $\begin{array}{l}\text { Political reform on the } \\
\text { political agenda. } \\
\text { Popular mobilization } \\
\text { against corruption that } \\
\text { begins in } 2013 \text { and } \\
\text { continues to present day. } \\
\text { Supreme Federal Court } \\
\text { rules corporate financing } \\
\text { unconstitutional (Sept. 2015) }\end{array}$ \\
\hline
\end{tabular}

SOURCE: Moraes and Andion, 2017. 
Analysing this trajectory, it is possible to observe that many incremental social innovations are produced throughout a "public inquiry" process (Andion et al, 2017). This notion derives from Dewey (1938) and from the concept of social inquiry. This research capacity refers to the ability of the publics to perceive and interpret the consequences of problematic situations, name them, identify them, build knowledge and propose solutions to them. In this sense, ordinary citizens are capable of a "cognitive attitude" (Cefaï, 2014: 14) and of adopting methods to cope with public problems.

As shown by Moraes and Andion (2017), in the MCCE this dynamic corresponds to a continuous and collective learning-by-doing process. This experimental learning is created by successive solutions that are put into practice by the actor-networks when responding to trial situations:

How does one design a popular initiative bill? How does one obtain the number of signatures required for its approval? How does one ensure its approval in Congress? How does one ensure the implementation of the law after it passes? In seeking answers to these "problematic situations", the actor-network analysed concluded that the answers were learning, creating new answers and thus "expanding the horizon of the possible" (Cefaï, 2009). In this sense, it can be concluded that social innovation in the public arena is configured as a process of "experimentation", which involves trials and errors, advances and setbacks.

More particularly, in this case, different agents involved in these networks co-produce knowledge and thus constitute themselves as "public" (Dewey, 1927) and act in the co-construction of new possibilities in the public arena of electoral corruption.

4.2. Trajectory and performance of civil society organizations that promote services for children and adolescents

The research to understand CSOs' performance in the policy of protecting children and adolescents' rights was conducted in Florianopolis city, Brazil. The main research strategy was direct observation with an ethnographic approach. The field research was performed from July 2014 to August 2015 and involved two different and complementary stages. The first was research participation in community service activities, sponsored by the university in partnership with a local community foundation, to promote institutional development of 15 nonprofits registered with the Council for Children and Adolescents Rights (CMDCA) of Florianópolis. During this programme, the CSOs' managers were prompted to reflect on their roles and their participation in the System to Guarantee Children's and Adolescents' Rights (SGDCA). This reflection was developed through seminars with the participation of more than 80 policy managers and approximately 130 children and adolescents from public and private schools in the city. The second stage entailed observation in public spaces of connection for the actors who operate the SGDCA. The researcher attended 08 meetings of the CMDCA, 06 meetings of the Public Policies Committee and 03 meetings of the Public Policy Forum of Florianópolis between November 2014 and August 2015. These are important spaces for connection and discussion of the 
policies to guarantee children and adolescents' rights in the city and to comprehend the CSOs' performance in the public arenas (Gonsalves and Andion, 2017).

The analysis of the CSOs' performance in the local arena revealed that CSOs have primary responsibility for the social assistance policy for children and adolescents in the city. Florianópolis is the capital of the State of Santa Catarina in Southern Brazil. In 2015, the city had 470,000 inhabitants, and approximately $26 \%$ of the population (i.e., 89,000 people) were between 0 and 18 years old (Icom, 2017). Although Florianópolis is the capital with the highest human development index (HDI) in Brazil (Pnud, 2013), the reality of a large portion of children and adolescents in the city still presents several problems. According to research conducted in the city called Vital Signs (ICom, 2017), in 2016, 01 of 07 children was vulnerable to poverty. Only $67 \%$ of youth between 18 and 20 years old completed middle school. The local child protection agencies registered between 2013 and 2015 more than 7 thousand complaints of rights violations. Additionally, between 2007 and 2015, 556 cases of sexual abuse were investigated.

To fight this reality, most CSOs in the city provide vital services to combat violations of children and adolescents' rights. As the Vital Signs Report showed, CSOs are the only entities responsible for offering free public and specialized services for people with disabilities. Additionally, CSOs are responsible for $80 \%$ of community and family ties-strengthening services and shelter services (ICom, 2017). However, their relationship with the municipal government is based on the transfer of financial resources to sponsor the CSOs and their services. Although the grants are not sufficient to cover all the costs, the CSOs become dependent on the municipality to survive and operate, and in most cases, the services are precarious. This reality results in great concern for the CSOs related to grant mobilization, leaving behind concerns such as the quality of the services, advocacy or strengthening public policies.

In the public arena, high mobilization of the CSOs could be observed, especially in the CMDCA. However, analysing the issues discussed in the meetings, the most controversial questions were about CSO grant mobilization, mainly because the CMDCA is the city's manager of the children and adolescent fund, entitled to receive financial resources from companies that benefit from tax exemptions. Other controversies raised were: 1) low participation of the city government as part of the CMDCA; 2) lack of coordination between the actors in the network and between policies; 3 ) asymmetry in the relationship between the city government and the $\mathrm{CSO} ;$; 4 ) absence of accurate research about the situation of children and adolescents living in the city; 5) lack of transparency in the childhood and adolescence fund; and 6) a low degree of involvement of the legislative power in the SGDCA.

This shows that CSOs' public grammar in this case is centralized on bureaucratic and management issues. This "managerial" grammar is more often employed by the "policy officers" (CSO managers included) and is more often present in their concerns. This is quite different from the worries expressed by the children and adolescents themselves. When questioned about "public problems" linked with their rights, children and adolescents that participate of the seminars noted some preoccupations: How to ensure greater quality and sensitivity of medical care towards children and adoles- 
cents? How to improve the police approach to the adolescent offender? How to ensure greater appreciation of prevention of children and adolescents' diseases? How to address cases of violence and bullying in school? How to create spaces where children and adolescents can talk about their rights, obligations, freedoms and prejudices? How to ensure students the right to express themselves at school and closer relationships with principals, teachers and other students? It is noteworthy that the issues that mobilize CSOs and policy managers are distant from the concerns of children and adolescents (which are centred on the problems that they encounter in ordinary life).

Other important evidence from the research is the main strategy used to resolve the controversies. When CSOs need to mobilize against the municipality's lack of services or in cases of neglect of public care, the main strategy is to appeal to the public prosecutor for judicial action. In this sense, judicialization of these situations has been increasingly frequent.

The ECA and SGDCA were milestones that created a network of participatory governance for public policy on children and adolescents' rights. Although the analysis of CSOs' performance revealed that their practices are centred on combatting rights violations in an isolated and punctual manner rather than on collective and coordinated work to prevent and promote rights (before the situation becomes a violation of rights). In this case, it was possible to observe the wide gap between the legal and institutional framework and the consequences of this performance, which seem quite different from what is intended: a connected network that promotes the integral protection of children and adolescents.

Comparing the two cases, it is possible to conclude that ability to produce enduring social innovation are not the same in the two public arenas analysed. This difference seems to be related to their performance (their practices) or the way that they act in these fields and by the configuration of the two public arenas analysed.

In the arena of children and adolescents' rights, the CSOs are largely oriented to a logic of organizational survival and maintenance of their services. Their performances are focused on coproducing public services and guaranteeing the material conditions to do so. The orientation to "survive" seems to limit the "critical capacity" (Chateauraynaud, 2011) of the different publics engaged in these organizations. They seem to be focused more on organizational and public policy concerns than on putting into question and publicizing the problems confronted by children and adolescents in their daily lives, as shown. Another point of prominence is the search for resolution of the controversies through judicialization after the violations have already occurred, which is observed on the macro and micro scales in the arena of protection of children and adolescents' rights.

Comparing the two performances, more than two forms of influence, we can observe two modes of engagement and justification (Boltansky and Thevenot, 2006) in public arenas. This is more evident 
when we take into account the "trial situations" (Chateuraynaud, 2011) or the moments of "controversy" (Venturini, 2010a and 2010b), in which certainties are questioned and put in check, giving place to new meanings for justice. In the MCCE case, we can see that these moments produce experiential and collective learning, promoting important changes in the landscape of electoral corruption.

As observed in the MCCE case, the knowledge about electoral corruption was co-constructed by different collectives when facing "trial situations". They put in question the natural attitude and create new repertoires of arguments and practices and new "publics" (Quéré and Terzi, 2015). More than a functional logic turned to more efficiency in delivering public services, what results from the MCCE case is a public inquiry process that involves: (1) identification and denunciation of a public problem and its consequences; (2) an interpretation and debate about its causes and effects; (3) creation and diffusion of knowledge about the problem; (4) co-construction of responses to the public problem; and (4) systematization and dissemination of learning.

It can be concluded that the CSOs' influence on the democratization of political order is not a guarantee but rather an achievement (Andion et al, 2017). Additionally, it does not occur under ordinary conditions. In the MCCE case, it was possible through a process of "public inquiry" that occurs in a "community of experience" that produces shared meanings and practices (Zask, 2004: 6).

\section{5.- Final considerations}

The current literature on social innovation assumes that the social innovation process is characterized as individual or collective initiatives that are disruptive towards the status quo and create new solutions, i.e., "new ideas that work" (Mulgan et al., 2007, p. 8), in response to social problems. Analysing these texts - which are quite widespread in the fields of management and economics it is possible to see a functionalist perspective that highlights control and management of innovation. Social innovation is regarded as a cycle consisting of phases that can be stimulated and encouraged. The link between social innovation and social change is not a focal point. Social change is considered a consequence of the social innovation cycle, and it is defined as "systemic change involving new frameworks and architectures made of small changes" (Murray, Caulier Grice and Mulgan, 2010: 13). Finally, the discussion about the links among social innovation, the public sphere and the State is almost absent from this literature.

In the same way, studies that treat the influence of CSOs in the public sphere and the political process are, in general, normative. As Soule and Olzak (2004) conclude, although many researchers make assumptions about the causes of political change, few studies have examined these processes empirically. If we look at the recent studies about CSOs and social innovation (Jing and Gong, 2012; 
Galli et al., 2014; Gonzales et al., 2014; Franz, Tausz and Thiel, 2015; Seyfang and Longhurst, 2016), the conclusions are in the same sense. These studies, as shown by Andion et al, 2017, emphasize the functional and economic dimensions of social innovation, which is described as a way for CSOs to contribute to government and public policy. In this perspective, the political dimension of social innovations and their consequences in terms of social change are also little explored.

This research was conducted to respond to these gaps in the literature and to contribute to moving this debate forward. This study interprets social innovation as a process of co-definition and coownership of problematic situations, which occurs in "day-to-day politics" of the different publics mobilized around public problems (Andion et al, 2017). Social innovation, as the capacity to institute for new possible futures, does not occur in a vacuum, is not a linear process and does not have predictable consequences. To better comprehend this process, we investigated two experiences embedded in two different public arenas in Brazil: the fight against electoral corruption and the protection of children and adolescents' rights.

First, this study concludes that the social innovation initiatives promoted by CSOs are influenced by and have an effect on the "political culture" in the public arenas. As observed in the MCCE case, the mobilizations and their consequences promoted by the CSOs' network resulted in profound political change not only in institutional terms (with the creation of a new legal landmark) but also contributing to create a public opinion about the issue "electoral corruption". The action of the MCCE network was important to co-construct new meanings, engagements and perspectives about this public problem in time. Moreover, the MCCE collective action was also legitimate by this "framework of relevance" (Cefaï, 2014), established by this debate in the public arena configured historically. As stated by Cefaï (2009: 36), "collective action finds support in this public culture shared by its members, which offers options to take positions, provides the standing points at the battle arenas and suggests good expressive forms".

In the arena of protection of children and adolescents' rights, we observe that this "political culture" is influenced in the inverse sense. In other words, the trajectory of the debate goes from mobilization to institutionalization very quickly. The great engagement of civil society actors observed in the $1980 \mathrm{~s}$ and 1990s is followed by a demobilization, while the majority of CSOs assume the role of public service providers to guarantee the promotion of children and adolescents' rights. The great majority of the CSOs in Florianopolis city, as shown above, are oriented to the provision of public services, performing as municipal government-outsourced organizations.

Therefore, these considerations make it possible to explore the relation between the dynamics of social and political change in the public arenas analysed and the performance of CSOs. What can be concluded in this study is that the regime of engagement (Boltansky and Thévenot, 2006) of the CSOs and their performance have consequences in terms of influence in social and political changes.

The cases studied show that the more CSOs are oriented on the logic of organizational survival and service supply (Simsa, 2003), the less time and energy they have to influence social and political 
changes. The tendency here is to maintain regularity and practices more than putting into question what is taken for granted.

However, when the CSOs go beyond the logic of co-production of public services and engage in "public inquiry" processes (Quéré and Terzi, 2015), their capacity to promote social innovations and for influence in social and political change expands. By this process, CSOs seem to promote and diffuse knowledge and constitute as public (Dewey, 1927), affecting the co-construction of the social reality and the future in public arenas where they perform.

\section{6.- References}

ANDION, C., RONCONI, L., MORAES, R.L., GONSALVES, A.K.R., SERAFIM, L.B.D.S. (2017): "Civil society and social innovation in the public sphere: A pragmatic perspective", Revista de Administracão Pública, 51 (3), 369-387.

ANDION, C., BECKER, Y. \& VICTOR, I. (2012): "Is Private Social Investment a Form of Public Goods Coproduction? An Overview of the Brazilian Reality", Annals of Public and Cooperative Economics, 83, 407-433.

ARENDT, H. (1991): A condição humana, Rio de Janeiro: Forense Universitária.

BARTHÉ, Y. et al. (2013): "Sociologie Pragmatique: mode d'emploi”, Politix, 103, 175-204.

BERNIER, L., BOUCHARD, M. \& LÉVESQUE, B. (2003): "Attending to the general interest: New mechanisms for mediating between the individual, collective and general interest in Quebec", Annals of Public and Cooperative economics, 74 (3), 321-348.

BOLTANSKI, L. \& THÉVENOT, L. (2006): On Justification: Economies of Worth, Oxford: Princeton University Press.

CAJAIBE-SANTANA, G. (2014): "Social innovation: Moving the field forward. A conceptual framework", Technological Forecasting and Social Change, 82, 42-51.

CALLON, M. \& LATOUR, B. (1981): "Unscrewing the big leviathan: how actors macrostructure reality and how sociologists help them do so". In: Knorr-Cetina, K., Cicourcel, A.V. (Org.), Toward an integration of micro and macro sociologies, London: Routledge.

CEFAI, D. (2017): "Públicos, Problemas Públicos, Arenas Públicas. O que nos ensina o Pragmatismo (Parte 1)", Novos Estudos, CEBRAP, 36, 187-213. 
CEFAÏ, D. (2014): "Investigar los problemas públicos com más y allá de Joseph Gusfield". In: J.R. Gusfield, La cultura de los problemas públicos. Los conductores alcoholizados y el ordem simbólico, Buenos Aires: Siglovientiuno.

CEFAÏ, D. (2009): "Como nos mobilizamos? A contribuição de uma abordagem pragmatista para a sociologia da ação coletiva", Dilemas. Revista de Estudos de Conflitos e Controle social, 2 (4).

CEFAÏ, D. (2002): "Qu'est-ce qu'une arène publique? Quelques pistes pour une approche pragmatiste". In: Cefaï, D., Joseph, I. (Org.), L'Héritage du pragmatisme, Conflits d'urbanité et épreuves de civisme, Paris: La Tour d'Aigues, Éditions de l'Aube, 51-82.

CEFAï, D. \& TERZI, C. (2012): L'expérience des problèmes publics, Paris: Perspectives Pragmatistes.

CHATEAURAYNAUD, F. (2011): Argumenter dans un champ de forces. Essai de balistique sociologique, Paris: Editions Petra, 2011.

CHATEAURAYNAUD, F. (2016): "Pragmatique des transformations et sociologie des controverses". In: Chateuraynaud, F., Cohen, Y., Histoires pragmatiques, Raisons Pratiques, Paris : Editions de l'EHESS, 349-385.

COHEN, J.L. \& ARATO, A. (1994): Civil Society and Political Theory, Massachusetts: MIT Press.

DENHARDT, J.V. \& DENHARDT, R.B. (2003): The new public service: Serving, not steering. New York, ME Sharpe.

DEWEY, J. (1927): The Public and its problems, Chicago: Swallow Press.

DEWEY, J. (1938): Logica. Teoría de la investigation, México: Fondo de Cultura Economica.

FRANZ, Y., TAUSZ, K. \& THIEL, S.K. (2015): "Contextuality and Co-Creation Matter. A Qualitative Case Study Comparaision of Living Lab Concept in Urban Research", Technology Innovation Management Review, 5 (12), 48-55.

FREGA, R. (2016): "Quést-ce qu'une pratique?". In: Chateuraynaud, F., Cohen, Y., Histoires pragmatiques, Raisons pratiques, Paris: Editions de l'EHESS, 321-347.

GALLI, F., BRONORI, G., DI IACOVO, F. \& INNOCENTI, S. (2014): "Co-producing sustantability: involving parents and civil society in the governance of school meal services. A case study from Pisa, Italy", Sustaintability, 6 (4), 1643-1666.

GONSALVES, A.K.R. (2015): Sistema de Garantia de Direitos da Criança e do Adolescente como Ação Pública: Uma análise multiescalar no município de Florianópolis, Dissertação (Mestrado em Administração), Florianópolis, Universidade do Estado de Santa Catarina.

GONSALVES, A.K.R. \& ANDION, C. (2017): "Public Action and Social Innovation: dilemmas of democratic governance in the System to Guarantee Children and Adolescents Rights (SGDCA) in Florianópolis city, Brazil", Annales do Colloque International du CRISES, Montreal : CRISES. 
GONZÁLEZ, C.G. et al. (2014): "Social Farm in Catalonia (Spain): Social Innovation and agoecological dinamization as employement for exclusion", Ager, 17, 65-97.

GUSFIELD, J.R. (1981): The Culture of Public Problems Drinking-Driving and the Symbolic Order, Chicago: The University of Chicago Press.

HABERMAS, J. (1984): Mudança estrutural da esfera pública: investigações quanto a uma categoria da sociedade burguesa, Rio de Janeiro: Tempo Brasileiro.

HEISKALA, R. (2007): "Social Innovations: Structural and Power Perspectives". In: Hamalainen, T.J., Heiskala, R. (Org.): Social Innovations, Institutional Change and Economic Performance, Cheltenham: Edward Elgar, 52-79.

JING, Y. \& GONG, T. (2012): "Managed social innovation: the case of governement-sponsored venture philantropy in Shangai", Australian Journal of Public Administration, 71 (2), 233-245.

LASCOUMES, P. \& LE GALÈS, P. (2007): Sociologie de l'action publique, Paris: Armand Colin.

LATOUR, B. (2014): Course: Scientific Humanities, Paris, - Sciences Po. - MOOC from the FUN-2014. Available in: www.sciencespo. Accessed in 15 may 2014.

LATOUR, B. (2012): Reagregando o social: uma introdução à teoria do ator-rede, Salvador: EDUFBA.

LATOUR, B. (1999): "On recalling ANT". In: Law, J. \& Hassard, J., Actor Network Theory and After, Oxford: Blackwell publishing.

LATOUR, B. (1994): Jamais Fomos Modernos: um ensaio sobre antropologia simétrica, São Paulo: Editora 34.

LAW, J. (1999): "After ANT: complexity, naming and topology". In: Law, J. \& Hassard, J., Actor Network Theory and After, Oxford: Blackwell publishing.

LEHTOLA, V. \& STAHLE, P. (2014): "Societal innovation at the interface of the state and civil society", Innovation: The European Journal of Social Science Research, 27 (2), 152-174.

LÉVESQUE, B. (2014): "As Inovações Sociais Podem Contribuir para Transformações, Mas Isso Não é Tão Evidente”, Revista Ciências em Debate, 1 (2), 179-199.

MEYER, M. \& BUBER, R. \& AGHAMANOUKJAN, A. (2013): "In search of Legitimacy: Managerialism and Legitimation in Civil Society Organizations", Voluntas: International Journal of Voluntary and Nonprofit Organizations, 24, 167-193.

MERICKOVA, B.M., NEMEC, J. \& SVIDRONOVA, M. (2015): "Co-creation in local public services delivery innovation: Slovak experience", Lex Localis, 13 (3), 521-535.

MONTGOMERY, T. (2016): "Are Social Innovation Paradigms Incommensurable?", Voluntas: International Journal of Voluntary and Nonprofit Organizations, 27, 1979-2000. 
MORAES, R.L. (2014): "Ação coletiva e inovacção social na esfera pública: análise da experiência do Movimento de Combate à Corrupção Eleitoral (MCCE) no Brasil", 281 p. Dissertação de Mestrado. (Mestrado Acadêmico em Administração). Universidade do Estado de Santa Catarina, Florianópolis.

MORAES, R.L., ANDION, C. (2017 forthcoming): "Civil Society and Social Innovation in Public Arenas in Brazil: Trajectory and Experience of the Movement Against Electoral Corruption (MCCE)", Voluntas: International Journal of Voluntary and Nonprofit Organizations.

MULGAN, G., TUCKER, S., RUSHANARA, A. \& SANDERS, B. (2007): "Social Innovation: What is it, Why it Matters and How It Can be Accelerated". Working Paper, Oxford: Skoll Center for Social Entrepreneurship/Oxford Business School.

MUMFORD, M.D. (2002): "Social Innovation: Ten Cases from Benjamin Franklin", Creativity Research Journal, 14 (2), 253-266.

MURRAY, R., CAULIER-GRICE, J. \& MULGAN, G. (2010): The Open Book of Social Innovation, London: The Young Foundation.

NICHOLLS, A. (2010): "The Legitimacy of Social Entrepreneurship: Reflexive Isomorphism in a PreParadigmatic Field", Entrepreneurship Theory \& Practice, 34 (4), 611-633.

NICHOLLS, A. et al. (2015): New Frontiers in Social Innovation Research, London: Palgrave Macmillan UK.

OSBORNE, S.P. (2006): “The new public governance?”, Public Management Review, 8 (3), 377-387.

POL, E. \& VILLE, S. (2009): "Social Innovation: Buzz Word or Enduring Term?", The Journal of SocioEconomics, 38 (1), 878-885.

QUERE, L. \& TERZI, C. (2015): "Pour une sociologie pragmatiste de l'experience publique. Quelques apports mutuels de la philosophie pragmatiste et de l'ethnométhodologie", SociologieS, [en ligne]. Dossiers, Pragmatisme et sciences sociales: explorations, enquêtes, experimentations, 1-18.

RANA, N.P. et al. (2014): "Profiling Existing Research on Social Innovation in the Public Sector", Information Systems Management, 31 (3).

SEYFANG, G. \& LONGHURST, N. (2016): "What influences the diffusion of grassroots innovations for sustantability? Investigating community currency niches", Technology Analisys \& Strategic Management, 28 (1), 1-23.

SIMSA, R. (2003): "Fighting Heroes, Repair-Workers or Collaborators? Strategies of NPOs and their consequences", Financial Accountability and Management. 19 (3), 225-241.

SINCLAIR, S. \& BAGLIONI, S. (2014): "Social Innovation and Social Policy - Promises and Risks", Social Policy \& Society, 13 (3), 469-476.

SNOW, D.A., SOULE, S.A. \& KRIESI, H. (Ed.) (2004): The Blackwell Companion to Social Movements, Malden: Backwell Publishing. 
SOULE, S. \& OLZAK, S. (2004): "When Do Movements Matter? The Politics of Contingency and the Equal Rights Amendment", American Sociological Review, 69 (4), 473-497.

THOENIG, J.-C. \& DURAN, P. (1996): "L'Etat et la gestion publique territoriale", Revue française de science politique, 46 (4), 580-623.

VENTURINI, T. (2010a): "Building on faults: how to represent controversies with digital methods", Public Understanding of Science, 20 (10), 1-17.

VENTURINI, T. (2010b): "Diving in magma: How to explore controversies with actor-network theory", Public understanding of science, 9 (3), 258-273. 